\title{
STUDY AVAILABILITY OF WIND SPEED IN THE SOUTH COASTAL AREA OF GORONTALO REGENCY, INDONESIA
}

\author{
Arthur Gani Koto ${ }^{1}$ \\ ${ }^{1}$ Program Studi Geografi Universitas Muhammadiyah Gorontalo, Indonesia \\ Email Korespondensi: arthur@umgo.ac.id
}

DOI: $10.31314 /$ jsig.v3i2.664

Abstract - The location of Indonesia at the equator is a Hadley, Walker, and local circulation encounter area so that the condition is estimated to be rich in wind potential. The power capable of installing the 2016 PLN power plant from the Bayu Power Plant (PLTB) only meets 0.20 MW in Gorontalo. This study aims to study the availability of wind speed in the southern coastal region of Gorontalo Regency. Wind speed measurement using hand anemometer is carried out in two sessions for each village, namely session I between 10.00 - 12.00 WITA and session II between 16.00 - 18.00 WITA. There are five villages located on the southern coast of Gorontalo Regency as data collection locations, namely Bongo, Kayubulan, Bulihu Tengah, Luluo and Taulaa Villages. The selection of the village is based on its location in the District Capital, directly adjacent to Tomini Bay, easy access to location, and population. Data retrieval in the form of wind speed, location coordinates, air temperature, air pressure, and altitude. The results showed that the highest average wind speed occurred at the measurement of Session I in Taulaa Village at $4.2 \mathrm{~m} / \mathrm{s}$.

Keywords: renewable energy, win speed, gorontalo regency

\begin{abstract}
Abstrak - Letak Indonesia yang berada di wilayah khatulistiwa merupakan daerah pertemuan sirkulasi Hadley, Walker, dan lokal sehingga kondisi tersebut diperkirakan kaya akan potensi angin. Daya mampu kapasitas terpasang pembangkit tenaga listrik PLN Tahun 2016 dari Pembangkit Listrik Tenaga Bayu (PLTB) baru memenuhi 0,20 MW di Gorontalo. Penelitian ini bertujuan untuk mempelajari ketersediaan kecepatan angin di wilayah pesisir selatan Kabupaten Gorontalo. Pengukuran kecepatan angin menggunakan hand anemometer yang dilakukan dalam dua sesi untuk tiap desa yaitu sesi I antara pukul 10.00 - 12.00 WITA dan sesi II antara pukul 16.00 - 18.00 WITA. Terdapat lima desa yang letaknya di pesisir selatan Kabupaten Gorontalo sebagai lokasi pengambilan data yaitu Bongo, Kayubulan, Bulihu Tengah, Luluo, dan Taulaa. Pemilihan desa tersebut berdasarkan lokasinya yang berada di Ibukota Kecamatan, berbatasan langsung dengan Teluk Tomini, kemudahan akses lokasi, dan jumlah penduduk. Pengambilan data berupa kecepatan angin, koordinat lokasi, suhu udara, tekanan udara dan ketinggian. Hasil penelitian menujukkan bahwa kecepatan angin rata-rata tertinggi terjadi pada pengukuran Sesi I yang terjadi di Desa Taulaa yaitu 4,2 m/s.
\end{abstract}

Kata kunci: energi terbarukan, kecepatan angin, kabupaten gorontalo 


\section{INTRODUCTION}

Indonesia country, which is a maritime country with an area of $6,315,222 \mathrm{~km}^{2}$ with a coastline length of $99,093 \mathrm{~km}^{2}$ (Kardono, 2016), only utilizes $2.5 \mathrm{MW}$ as a source of wind energy from the target 1.8 GW (Statistik Ketenagalistrikan 2016, 2017). The location of Indonesia in the equator is the Hadley, Walker, and local circulation meeting area so that the condition is estimated to be rich in wind potential (Habibie et al., 2011). The Indonesian government's program for 35 thousand MW of renewable energy has not been fulfilled until this time. Inauguration of the PLTB in Sidrap, South Sulawesi, which produces 75 MW of electricity is the largest in Southeast Asia, answering the seriousness of the Government of Indonesia in the availability of renew able energy. At the same time, in Jeneponto Regency, South Sulawesi is also running the construction of a PLTB of $72 \mathrm{MW}$.

Population growth accompanied by increased consumption of fossil fuels can cause its availability to be depleted. The use of renewable energy sources is important as alternative energy besides fossil fuels (Sliz-Szkliniarz \& Vogt, 2011). Until now, petroleum is still the main energy source in meeting the needs in Indonesia. The availability of fossil-based energy is an important issue because of the depletion of petroleum reserves because they are non-renewable which can directly threaten the supply of fuel and electricity for the community.

One very large wind power potential occurs in the region of the ocean with land because of the difference in absorption of sunlight so that high air pressure is formed which can cause air movement to flow rapidly. Air flow and wind speed can vary in type depending on local topographic characteristics (Aydin et al., 2010). The average minimum wind speed that can be used economically as a provider of energy sources is $4 \mathrm{~m} / \mathrm{s}$ (Lubis, 2007).

\section{METHODS AND DATA}

Metoda Geographically, Gorontalo Regency has a coastal area located in the southern part, extending from west-east and bordering Tomini Bay. Gorontalo Regency is one of the Gorontalo Province administrative regions which has an area of 2,125.47 $\mathrm{km}^{2}$ with its capital Limboto District (Kabupaten Gorontalo Dalam Angka, 2017). Based on its geographical position has boundaries: North-North Gorontalo Regency, South-Tomini Bay, West-Boalemo Regency, and East-Bone Bolango Regency and Gorontalo City.

Gorontalo Regency has 19 sub-districts, where three sub-districts are located in the southern coastal area bordering Tomini Bay. The three sub-districts are Bilato sub-district (10 villages), Biluhu sub-district (8 villages), and sub-district Batudaa Pantai (9 villages), as presented in Table 1. Bilato sub-district is a division of regions from Boliyohuto sub-district in 2010 years (Peraturan Menteri Dalam Negeri Republik Indonesia Nomor 56, 2015). Some villages located on the southern coast of Gorontalo Regency are presented in Figure 1. The Taulaa village in Bilato Subdistrict is the only village directly adjacent to Tomini Bay. Whereas all villages in Biluhu and Batudaa Pantai sub-districts are directly adjacent at Tomini Bay.

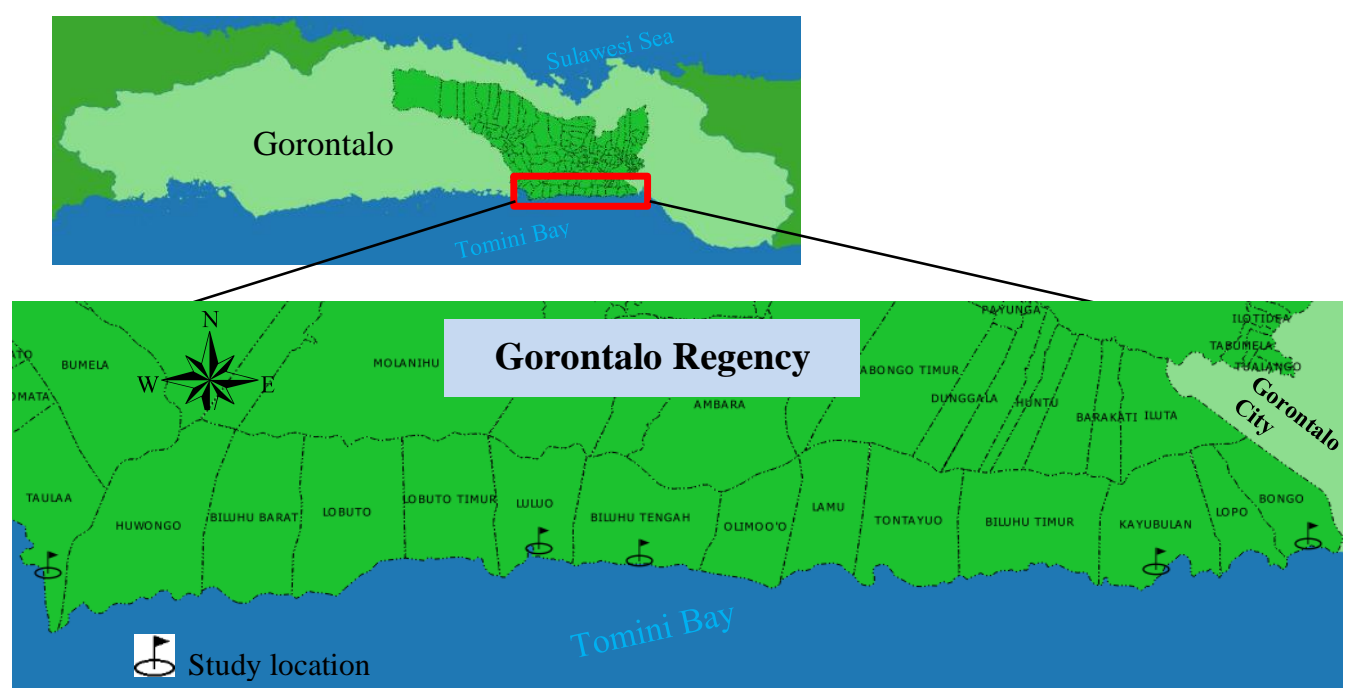

Fig 1. Some villages in the south coastal area of Gorontalo Regency 


\section{Dataset}

This study used the Hand Anemometer, Global Positioning System (GPS), and Humidity Meter. The data used consists of Rupa Bumi Indonesia (RBI) digital map scale 1: 50,000 issued in 1991 years, BPS-KEMENTAN digital map issued in 2010 years.

\section{Methods}

This research is located in several villages located in the southern coastal region of Gorontalo Regency. Some of these villages are located directly adjacent to Tomini Bay. These villages are Bongo and Kayubulan (Batudaa Pantai sub-district), Taulaa (Bilato subdistrict), Lobuto Timur, Biluhu Tengah and Luluo (Biluhu sub-district). The reason for choosing some of these villages is based on the following four things, namely the location which is in the sub-district capital, directly adjacent at Tomini Bay, easy access to location, and a large population.

The location coordinates for measuring wind speed are obtained from the RBI map analysis which is used as a guide in the field for observation. GPS used for retrieving coordinate measurements and guides to a predetermined location. Determination of the location coordinate of measurement of wind speed is in a higher place, open place and still around the coastal area that still gets the sea wind directly so that the maximum wind speed obtained.

Wind speed measurement using a hand anemometer is carried out in two sessions for each village namely Session I between $10.00 \mathrm{am}-12.00 \mathrm{pm}$ and Session II between $4.00 \mathrm{pm}-6.00 \mathrm{pm}$. The timing of the measurement was carried out with the assumption that in session I there was a difference in the intensity of absorption of sunlight between land and sea. While in session II the intensity of sunlight absorption began to decrease.

\section{Results dan Discussion}

Data collection was carried out in March - May 2018. Location of data collection was based on analysis of digital RBI maps located in five villages, namely Kayubulan, Bongo, Central Biluhu, Luluo, and Taulaa, as in Figure 2. These five villages are directly adjacent to Tomini Bay.

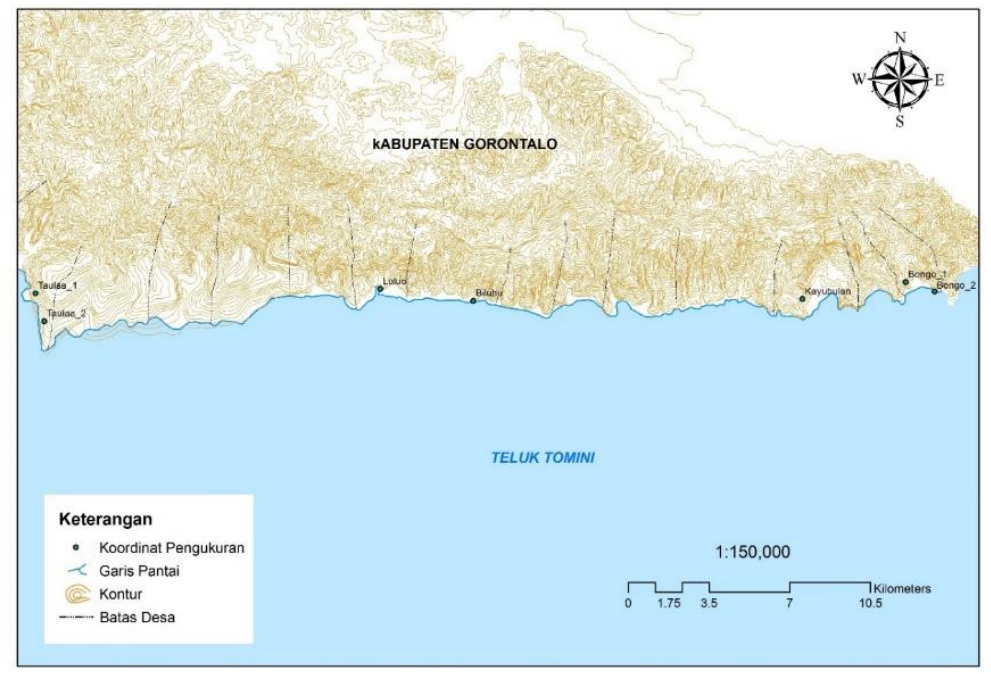

Fig 2. Location of data collection

The measurement results in session I show that all point coordinate of the measurement location has a minimum value of 0 except the Biluhu Tengah Village $\left(\mathrm{N} 0.49339^{\circ} \mathrm{E} 122.98866^{\circ}\right)$ has a minimum wind speed of $0.3 \mathrm{~m} / \mathrm{s}$ with a elevation of $52 \mathrm{~m}$. At session II, the maximum wind speed was obtained in Taulaa Village $\left(\mathrm{N} 0.48470^{\circ} \mathrm{E} 122.69293^{\circ}\right)$ at a speed of $3.2 \mathrm{~m} / \mathrm{s}$ at an altitude of $88 \mathrm{~m}$. 
Table 1. Field measurement results (source: field check, 2018)

\begin{tabular}{|c|c|c|c|c|c|c|c|c|}
\hline \multirow[t]{2}{*}{ Date } & \multirow[t]{2}{*}{ Time } & \multirow{2}{*}{$\begin{array}{c}\text { Coordinate } \\
\text { location } \\
\text { (latlon) }\end{array}$} & \multirow{2}{*}{$\begin{array}{l}\text { Altitude } \\
\text { (m) }\end{array}$} & \multirow{2}{*}{$\begin{array}{c}\text { Air } \\
\text { temperature } \\
\left({ }^{0} \mathrm{C}\right)\end{array}$} & \multicolumn{2}{|c|}{$\begin{array}{l}\text { Wind speed } \\
(\mathrm{m} / \mathrm{s})\end{array}$} & \multirow{2}{*}{$\begin{array}{c}\text { Air } \\
\text { Pressure } \\
\text { (mbar) }\end{array}$} & \multirow[t]{2}{*}{ Village } \\
\hline & & & & & $\min$ & $\max$ & & \\
\hline \multirow{5}{*}{$\begin{array}{l}\text { March } \\
11, \\
2018\end{array}$} & Session & $\mathrm{N} 0.5^{0}$ & & & & & & \\
\hline & I & E123.029 & 142 & 32 & 0 & 2.1 & 995.8 & Bongo \\
\hline & & $\begin{array}{l}\text { N0.493 } \\
\text { E122.988 }\end{array}$ & 158 & 33 & 0 & 2.1 & 993.4 & Kayubulan \\
\hline & $\begin{array}{l}\text { Session } \\
\text { II }\end{array}$ & $\begin{array}{l}\text { N0.493 } \\
\text { E122.988 }\end{array}$ & 158 & 33 & 0 & 1.2 & 991.4 & Kayubulan \\
\hline & & $\begin{array}{l}\text { N0.496 } \\
\text { E123.04 }\end{array}$ & 5 & 32 & 0 & 1.7 & 1007.9 & Bongo \\
\hline \multirow{5}{*}{$\begin{array}{l}\text { April } \\
15, \\
2018\end{array}$} & Session & N0.493390 & & & & & & Biluhu \\
\hline & I & E122.98866 & 52 & 34 & 0.3 & 2.6 & 1006.0 & Tengah \\
\hline & & $\begin{array}{l}\text { N0.49731 } \\
\text { E122.82406 }\end{array}$ & 51 & 34 & 0 & 1.0 & 1006.9 & Luluo \\
\hline & $\begin{array}{l}\text { Session } \\
\text { II }\end{array}$ & $\begin{array}{l}\text { N0.49731 } \\
\text { E122.82406 }\end{array}$ & 51 & 33 & 0 & 0.6 & 1003.8 & Luluo \\
\hline & & $\begin{array}{l}\text { N0.49339 } \\
\text { E122.98866 }\end{array}$ & 52 & 29 & 0 & 0.9 & 1005.1 & $\begin{array}{l}\text { Biluhu } \\
\text { Tengah }\end{array}$ \\
\hline \multirow[t]{2}{*}{$\begin{array}{l}\text { May 7, } \\
2018\end{array}$} & $\begin{array}{l}\text { Session } \\
\text { I }\end{array}$ & $\begin{array}{l}\text { N0.49557 } \\
\text { E122.68945 }\end{array}$ & 17 & 32 & 0 & 4.2 & 1011.4 & Taulaa \\
\hline & $\begin{array}{l}\text { Session } \\
\text { II }\end{array}$ & $\begin{array}{l}\text { N0.48470 } \\
\text { E122.69293 }\end{array}$ & 88 & 32 & 0 & 3.2 & 1002.8 & Taulaa \\
\hline
\end{tabular}

The topography of the village which is located in the southern coastal region of Gorontalo Regency has a hilly ontour in the north, so that measurement of wind speed is not obstructed from vegetation or other objects. Kayubulan Village has the most population, which is 2,525 people and Luluo Village has the smallest population of 654 people.

The five villages are dominated by hilly topography to the north and south along the coastline is a residential area. The hilly area is used by residents for agricultural land use, such as corn and coconut. Population activity is dominated by fishermen and farmers (corn and coconut). Electricity sources for the daily life of villagers come from PLN. The measurement results in March - May showed that the highest average wind speed occurred in Session I with a speed of $2.4 \mathrm{~m} / \mathrm{s}$ than in Session II which was $1.52 \mathrm{~m} / \mathrm{s}$.

\section{Bongo Village}

Bongo Village is located in Batudaa Pantai sub-district which is directly adjacent to Gorontalo City on the west. Bongo Village has an area of $1.5 \mathrm{~km}^{2}$ or $1.75 \%$ of the total area of Pantai Batudaa sub-district. Topography consists of hills to the north with the land use of corn and coconut plants. People work as farmers, fishermen, and trade. Road facilities in the form of asphalt are good and relatively easy to reach from Gorontalo City.

Data collection was conducted on March 11, 2018, which was carried out in two sessions and different coordinate positions. Session I at coordinates N0.5 E123.029 obtained maximum wind speed of $2.1 \mathrm{~m} / \mathrm{s}$, air pressure of $995.8 \mathrm{mbar}$, a elevation of $142 \mathrm{~m}$, air temperature of $32^{\circ} \mathrm{C}$. Bright weather conditions when collecting data and not obstructed by vegetation or other objects. Land use at the data collection location is dryland farming.

Retrieval of data in session II was carried out at coordinates N0,96 ${ }^{0} \mathrm{E} 123,04^{0}$ which were not far from the coast with wind speeds of $1.7 \mathrm{~m} / \mathrm{s}$, an altitude of $5 \mathrm{~m}$, air temperature of $32^{\circ} \mathrm{C}$ and air pressure of 1007.9 mbar. The choice of position is due to other locations being obstructed by vegetation, hills (there is no road access).

\section{Kayubulan Village}

Located in Batudaa Pantai sub-district with an area of $14 \mathrm{~km}^{2}$ and is the sub-district capital. Topography consists of hills to the north with dryland farming (corn, and coconut). Easy accessibility is reached from Gorontalo City with a time about 20 minutes. Road facilities consist 
of smooth asphalt conditions and some of the asphalt conditions are moderately damaged. Settlements are along the right and left of the road.

Data collection was conducted on March 11, 2018, in two sessions with sunny weather conditions. Session I is located at coordinates N0.493 ${ }^{\circ} \mathrm{E} 122.988^{\circ}$ with the wind speed of $2.1 \mathrm{~m} / \mathrm{s}$, a elevation of $158 \mathrm{~m}$, air temperature of $33^{\circ} \mathrm{C}$, and air pressure of 993.4 mbar. Session II at coordinates position equal to the session I, wind speed $1.2 \mathrm{~m} / \mathrm{s}$, air temperture of $33^{\circ} \mathrm{C}$, air pressure 991,4 mbar. Land use is dominated by dryland farming.

\section{Biluhu Tengah Village}

Bilihu Tengah Village is located in Biluhu sub-district and is the largest village $\left(42 \mathrm{~km}^{2}\right)$. In the Biluhu Tengah Village, there is the SMUN 1 Biluhu. Similar to other villages, this village consists of the topography of hills in the north with dryland farming (corn, and coconut). Road facilities including asphalt category are heavily damaged, so caution is needed when driving.

Data collection was conducted on April 15, 2018, which was conducted in two sessions. Session I is located at coordinates $\mathrm{N} 0.49339^{\circ} \mathrm{E} 122.98866^{\circ}$, with wind speeds of $2.6 \mathrm{~m} / \mathrm{s}$, a elevation of $52 \mathrm{~m}$, air temperature of $34^{\circ} \mathrm{C}$, and air pressure of $1.006 \mathrm{mbar}$. The location in session II, the same as the coordinates in session I, has a wind speed of $0.9 \mathrm{~m} / \mathrm{s}$, air temperature of $29^{\circ} \mathrm{C}$, and an air pressure of 1005.1 mbar.

\section{Luluo Village}

This village is still in the administration of Biluhu Disub-dtrict and is located east of Biluhu Tengah Village. The topography of hills in the north with dryland farming (corn, and coconut). Road facilities including the asphalt category are heavily damaged. Public facilities in the form of markets are located in Luluo Village. This village is the least populated village (654 people) among the other five villages.

Data collection was conducted on April 15, 2018, which was conducted in two sessions. Session I is located at coordinates $\mathrm{N} 049731^{\circ} \mathrm{E} 122.82406^{\circ}$ with the wind speed of $1.0 \mathrm{~m} / \mathrm{s}$, air temperature of $34^{\circ} \mathrm{C}$, a elevation of $51 \mathrm{~m}$, and air pressure of $1006.9 \mathrm{mbar}$. The location in session II, the same as the coordinates in session I, has a wind speed of $0.6 \mathrm{~m} / \mathrm{s}$, air temperature of $33^{\circ} \mathrm{C}$, and air pressure of 1003.8 mbar. Bright weather conditions during data collection.

\section{Taulaa Village}

Taulaa Village is located in Bilato sub-district with a flat topography up to the hills. There is a downstream Paguyaman River in the west of the village. This village is the only one in Bilato sub-district which is directly adjacent to Tomini Bay. Dominated by dryland farming (corn and coconut). Roads in the form of asphalt are good and easy to reach. Data collection was conducted on May 6, 2018, which was conducted in two sessions and two different positions. Session I at coordinates $049557^{\circ} \mathrm{E} 122.68945^{\circ}$, wind speed of $4.2 \mathrm{~m} / \mathrm{s}$, a elevation of $17 \mathrm{~m}$, air temperature of $32^{\circ} \mathrm{C}$, and air pressure of 1011.4 mbar. Session II at coordinates N0.48470 ${ }^{\circ} 122.69293^{\circ}$, wind speed $3.2 \mathrm{~m} / \mathrm{s}$, a elevation $88 \mathrm{~m}$, air temperature $32^{\circ} \mathrm{C}$, and air pressure $1002.8 \mathrm{mbar}$. There is sunny weather during data collection.

The highest wind speed occurs in Taulaa Village, which is $4.2 \mathrm{~m} / \mathrm{s}$. Biluhu Tengah Village has a minimum wind speed of $0.3 \mathrm{~m} / \mathrm{s}$ at the session I and at session II at least $0 \mathrm{~m} / \mathrm{s}$. Luluo village has the smallest maximum wind speed among other villages, which is $0.6 \mathrm{~m} / \mathrm{s}$ in session II.

\section{CONCLUSION}

The measurement of wind speed is carried out one day each month for three consecutive months (March-May). Wind speed in the southern coastal areas of Gorontalo Regency when measuring never reaches $5 \mathrm{~m} / \mathrm{s}$ and at certain times the wind does not blow. The month is a transition season rainy to dry season and sunny weather conditions at the time of measurement. The obtained wind speed can be used as a source of energy by building large-scale small-scale windmills, combined with solar power (photovoltaic).

Data collection is needed every month to analyze the quantity of electrical energy produced each month. It is necessary to measure wind speed for years so that maximum results can be obtained and find out the differences every time. 


\section{ACKNOWLEDGEMENTS}

We gratefully acknowledge the funding from USAID through the SHERA program - Center for Development of Sustainable Region (CDSR).

\section{REFERENCE}

Aydin, N. Y., Kentel, E., \& Duzgun, S. (2010). GIS-based environmental assessment of wind energy systems for spatial planning: A case study from Western Turkey. Renewable and Sustainable Energy Reviews, 14, 364-373. https://doi.org/10.1016/j.rser.2009.07.023

Habibie, M. N., Sasmito, A., \& Kurniawan, R. (2011). Kajian Potensi Energi Angin Di Wilayah Sulawesi dan Maluku. Jurnal Meteorologi dan Geofisika, 12(2), 181-187.

Kabupaten Gorontalo Dalam Angka. (2017). Badan Pusat Statistik.

Lubis, A. (2007). Energi Terbarukan Dalam Pembangunan Berkelanjutan. Jurnal Teknik Lingkungan, 8(2), 155-162.

Peraturan Menteri Dalam Negeri Republik Indonesia Nomor 56. (2015). Kode dan Data Wilayah Administrasi

Pemerintahan.

http://webcache.googleusercontent.com/search?q=cache:3mhoTOjo1cYJ:ditjenpp.kemenkumha m.go.id/arsip/bn/2015/bn1045-2015.pdf $+\& \mathrm{~cd}=1 \& \mathrm{hl}=\mathrm{en} \& \mathrm{ct}=\mathrm{clnk} \& \mathrm{gl}=\mathrm{id}$

Sliz-Szkliniarz, B., \& Vogt, J. (2011). GIS-based approach for the evaluation of wind energy potential: A case study for the Kujawsko-Pomorskie Voivodeship. Renewable and Sustainable Energy Reviews, 15, 1696-1707. https://doi.org/10.1016/j.rser.2010.11.045

Statistik Ketenagalistrikan 2016 (p. 44). (2017). Direktorat Jenderal Ketenagalistrikan Kementerian Energi dan Sumber Daya Mineral. 